\title{
Encephalomyocarditis Virus Induced Diabetes Mellitus in Mice: Long-term Changes in the Structure and Function of Islets of Langerhans
}

\author{
K. Iwo ${ }^{1}$, S.C. Bellomo ${ }^{2}$, N. Mukai ${ }^{3}$ and J. E. Craighead ${ }^{2}$ \\ ${ }^{1}$ Department of Internal Medicine, Wakayama Medical School, Wakayama, Japan, ${ }^{2}$ Department of Pathology, University of Vermont College \\ of Medicine, Burlington, Vermont and ${ }^{3}$ Department of Neuropathology and Neuro-ophthalmology, Harvard Medical School, Boston, \\ Massachusetts, USA
}

\begin{abstract}
Summary. Adult male mice infected with the $M$ variant of encephalomyocarditis virus develop hyperglycaemia acutely as a consequence of B cell injury. The severity of the metabolic disease is variable and many animals become normoglycaemic during convalescence. The islets of Langerhans of these mice exhibit minor structural changes, but there are no significant abnormalities of insulin and glucagon secretion. In contrast, animals with persistent hyperglycaemia exhibit striking
\end{abstract}

morphological alterations in the islets. The A cell mass is prominent, whereas B cells are reduced in number and exhibit striking cytological features. These changes are associated with both hypoinsulinaemia and hyperglucagonaemia.

Key words: Encephalomyocarditis virus, islets of Langerhans, insulin and glucagon metabolism, morphological, mouse.
The diabetogenic $\mathbf{M}$ variant of encephalomyocarditis (EMC) virus attacks pancreatic B cells of some but not all strains of mice [1-3]. Morphological and biochemical studies have failed to demonstrate injury to A cells during or immediately after the acute stages of infection [4-6]. The function of these cells, however, appears to be altered when isolated islets and monolayer cultures of islet tissue are exposed to the virus in vitro $[7,8]$. Using immunohistochemistry, Stefan et al. [9] noted a reduction in the number of $B$ cells during the acute infection and invasion of the islets by non-B, glucagoncontaining cells from the periphery of the islets in early convalescence.

Changes in the cell populations of the islets in mice developing chronic diabetes after EMC virus infection have not been investigated. In the studies reported here, we document alterations in $\mathrm{A}$ and $\mathrm{B}$ cell function during late convalescence and record morphological observations on the cellular composition of the islets.

\section{Materials and Methods}

\section{Animals}

Male 12-week-old CD-1 mice (Charles River Breeding Laboratories, Wilmington, Massachusetts, USA) were maintained on a 12-h light/ dark cycle with food and water ad libitum as described previously [1]. Metabolic cages were used to collect urine and to determine food and water consumption. Animal weights were determined at weekly inter- vals. Mice were administered phosphate-buffered saline $(0.5 \mathrm{ml})$ by gastric tube on occasion when evidence of severe dehydration occurred after a series of bleedings. As control animals, 25 sex and agematched normal mice from the same origin were kept and observed under similar conditions, but without virus inoculation.

\section{Virus}

The origin of the M variant of EMC virus and its preparation have been described previously [10]. Mice were infected by the intraperitoneal route with approximately 100 plaque-forming units in $0.2 \mathrm{ml}$ of $0.85 \%(0.15 \mathrm{mmol} / 1)$ Hanks' balanced salt solution buffered with $0.06 \mathrm{~mol} / 1$ phosphate.

\section{Glucose Tolerance Tests}

Methoxyflurane-anaesthetized animals were inoculated by the intraperitoneal route with $2 \mathrm{mg} / \mathrm{g}$ body weight of glucose of buffered $0.85 \% \mathrm{NaCl}(0.5 \mathrm{ml})$. Blood was obtained from the femoral vein before and at intervals after the administration of glucose, using an indwelling Teflon catheter (external diameter $=1 \mathrm{~mm}$, Top Venula catheter, Top Corporation, Tokyo, Japan; Fig. 1). The blood was collected in heparinized microhaematocrit tubes and the glucose concentration determined by the glucose oxidase method using a Yellow Springs Instrument Model 23A analyzer (Yellow Springs Instruments, Yellow Springs, Ohio, USA).

Blood was obtained for insulin and glucagon determinations from the catheter, and after immediate addition of aprotinin $(500 \mathrm{KIU} / \mathrm{ml}$, Trasyrol, Bayer, Leverkusen, FRG) the plasma was separated in the cold and stored deep frozen. Plasma insulin and glucagon concentrations were determined by radioimmunoassay. In the radioimmunoassay, the within assay coefficient of variation was $7 \%$ for $2.0 \mathrm{mU} / 1$ of insulin (in terms of rat insulin standard). Anti-glucagon antiserum: 
$30 \mathrm{~K}$ (Unger) worked at a within assay coefficient of variation $<11 \%$ for $30 \mathrm{pmol} / 1$.

Urinary glucose was assayed using Tes-Tape (Eli Lilly, Indianapolis, Indiana, USA).

\section{Morphological Studies}

Pancreatic tissue was fixed in Bouin's solution for approximately $6 \mathrm{~h}$ and transferred to buffered formalin for storage. After routine preparation, histological sections were stained with haematoxylin and eosin or by the immunoperoxidase technique. Rabbit anti-insulin and antiglucagon $(30 \mathrm{~K})$ serum were used in conjunction with peroxidase-conjugated anti-rabbit immunoglobulin raised in goats (Cappel Laboratory, Cochranville, Pennsylvania, USA). Ultrastructual studies were carried out on glutaraldehyde-fixed tissue using standard techniques.

\section{Statistical Analysis}

Student's t-test was used to examine differences between the mean values. A method after Cochran-Cox was used to ascertain significantly different fluctuations of insulin or glucagon concentrations between the animal groups during glucose tolerance tests.

\section{Results}

The virological and metabolic features of the acute infectious process in EMC infected mice and the subsequent occurrence of metabolic abnormalities have been recorded in detail elsewhere $[1,5,11]$. Studies of infected animals in the present series of experiments yielded similar results. As noted previously, mortality and the occurrence of glycosuria were variable in animals of a similar age and size. Although factors which might account for differences in the severity of diabetes were not identified, previous work strongly suggests that metabolic host influences are important [12].

For the purposes of this report, infected animals were assigned to three groups based on either the presence or absence of glycosuria and its persistence during convalescence (Table 1).

A small number of randomly selected members of the three groups were studied 3 months after infection to characterize the metabolic disease (Table 2). Animals in groups 1 and 2 did not differ significantly from controls, although the mice in both groups tended to eat more and gain less weight than age-matched controls. On the other hand, the weight of mice with persistent glycosuria (group 3) was reduced significantly and these animals manifested marked polyuria and polyphagia.

The results of studies of islet cell function in these same animals 5 months after virus inoculation are summarized in Figure 1. As might be expected, glucose intolerance was evident in animals of groups 2 and 3. These alterations in metabolic function were associated with a substantial decrease in insulin release in response to a glucose challenge. The glucagon concentrations in the blood of controls and members of group 1 tended to decrease after the administration of carbohydrate. In contrast, the blood glucagon concentration of the fast-
Table 1. Mortality of EMC virus infected animals by category of disease severity 3 months after virus inoculation

\begin{tabular}{llllll}
\hline $\begin{array}{l}\text { Number } \\
\text { infected }\end{array}$ & $\begin{array}{l}\text { Number } \\
\text { dead }\end{array}$ & $\begin{array}{l}\text { Surviving animals at } \\
3 \text { months }\end{array}$ & $\begin{array}{l}\text { Uninfect- } \\
\text { ed } \\
\text { controls }\end{array}$ \\
\cline { 3 - 6 } & Group 1 & Group 2 & Group 3 & \\
\hline 80 & $32(40 \%)$ & $14(29 \%)^{\mathrm{a}}$ & $11(25 \%)^{\mathrm{a}}$ & $23(46 \%)^{\mathrm{a}}$ & $25^{\mathrm{b}}$ \\
\hline
\end{tabular}

Group 1: no glycosuria; group 2: transient glycosuria (ie, glycosuria for $<3$ months after inoculation of virus); group 3: persistent glycosuria for $>3$ months; "percentage of the 48 mice surviving at 3 months in parentheses; ' without 'diabetic' death

Table 2. Physiological features of infected and non-infected mice after 3 months

\begin{tabular}{lllll}
\hline & $\begin{array}{l}\text { Urine } \\
\text { glucose } \\
\text { (mg/day) }\end{array}$ & $\begin{array}{l}\text { Urine } \\
\text { volume } \\
\text { (ml/day) }\end{array}$ & $\begin{array}{l}\text { Body } \\
\text { weight } \\
(\mathrm{g})\end{array}$ & $\begin{array}{l}\text { Food } \\
\text { intake } \\
\text { (g/day) }\end{array}$ \\
\hline $\begin{array}{l}\text { Uninfected } \\
\text { controls } \\
(n=25)\end{array}$ & Negative & $0.95 \pm 0.15$ & $48.6 \pm 4.0$ & $3.48 \pm 1.4$ \\
$\begin{array}{l}\text { Group } 1 \\
(n=5)\end{array}$ & Negative & $0.99 \pm 0.20$ & $44.5 \pm 5.7$ & $3.77 \pm 1.7$ \\
$\begin{array}{l}\text { Group 2 } \\
(n=5)\end{array}$ & Negative & $1.04 \pm 0.22$ & $43.4 \pm 5.9$ & $4.76 \pm 1.9$ \\
$\begin{array}{l}\text { Group 3 } \\
(n=6)\end{array}$ & $540 \pm 110$ & $32.7 \pm 6.1$ & $34.2 \pm 3.6$ & $8.0 \pm 0.37$ \\
\hline
\end{tabular}

Results expressed as mean $\pm \mathrm{SD}$
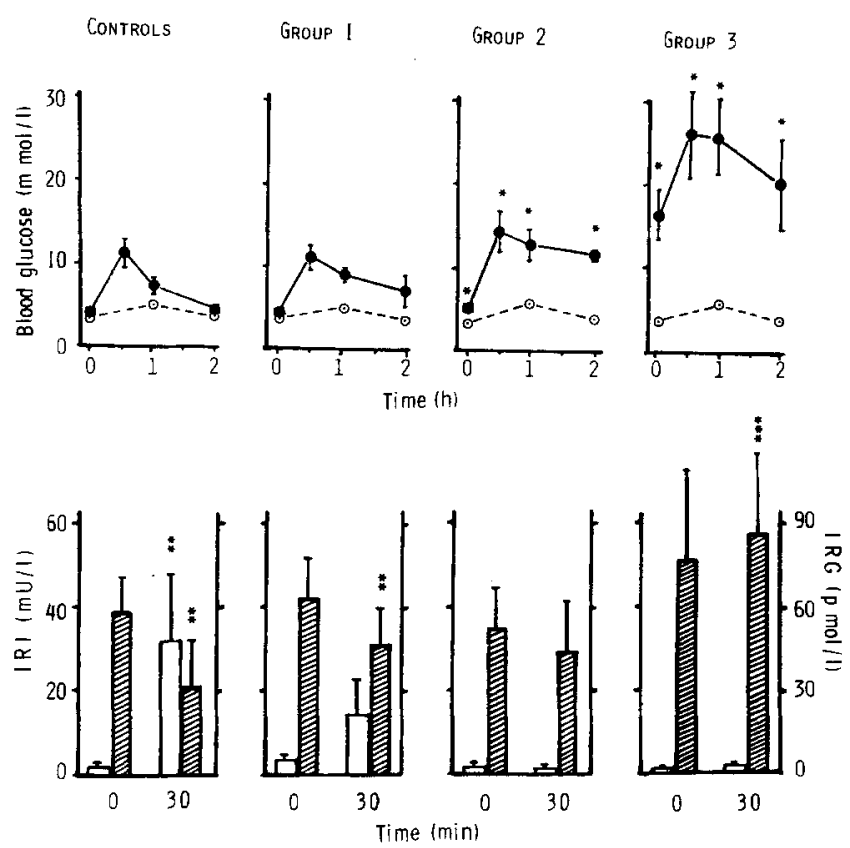

Fig. 1. Pancreatic islet cell function in uninfected control mice and the three infected study groups 5 months after infection with EMC virus. Control (no glycosuria, $n=5$ ); group 1 (no glycosuria, $n=7$ ); group 2 (transient glycosuria, $n=4$ ); group 3 (persistent glycosuria, $n=5$ ). Upper panel: Blood glucose concentrations at 1 and $2 \mathrm{~h}$ after intraperitoneal administration of $2 \mathrm{mg} / \mathrm{g}$ of giucose. $\mathrm{O} \ldots \ldots$ - $--0=$ pre-infection; - $=$ post-infection. *Values significantly higher than controls at corresponding time $(p<0.05)$. Lower panel: Plasma immunoreactive insulin and glucagon before and $30 \mathrm{~min}$ after administration of $2 \mathrm{mg} / \mathrm{g}$ of glucose. $\square$ - IRI; $\square$ - IRG. * Values significantly different from basal concentrations $(p<0.05)$. * IRG suppression significantly less than in the other groups ( $p<0.05$ by t-test after CochranCox's simulation method) 

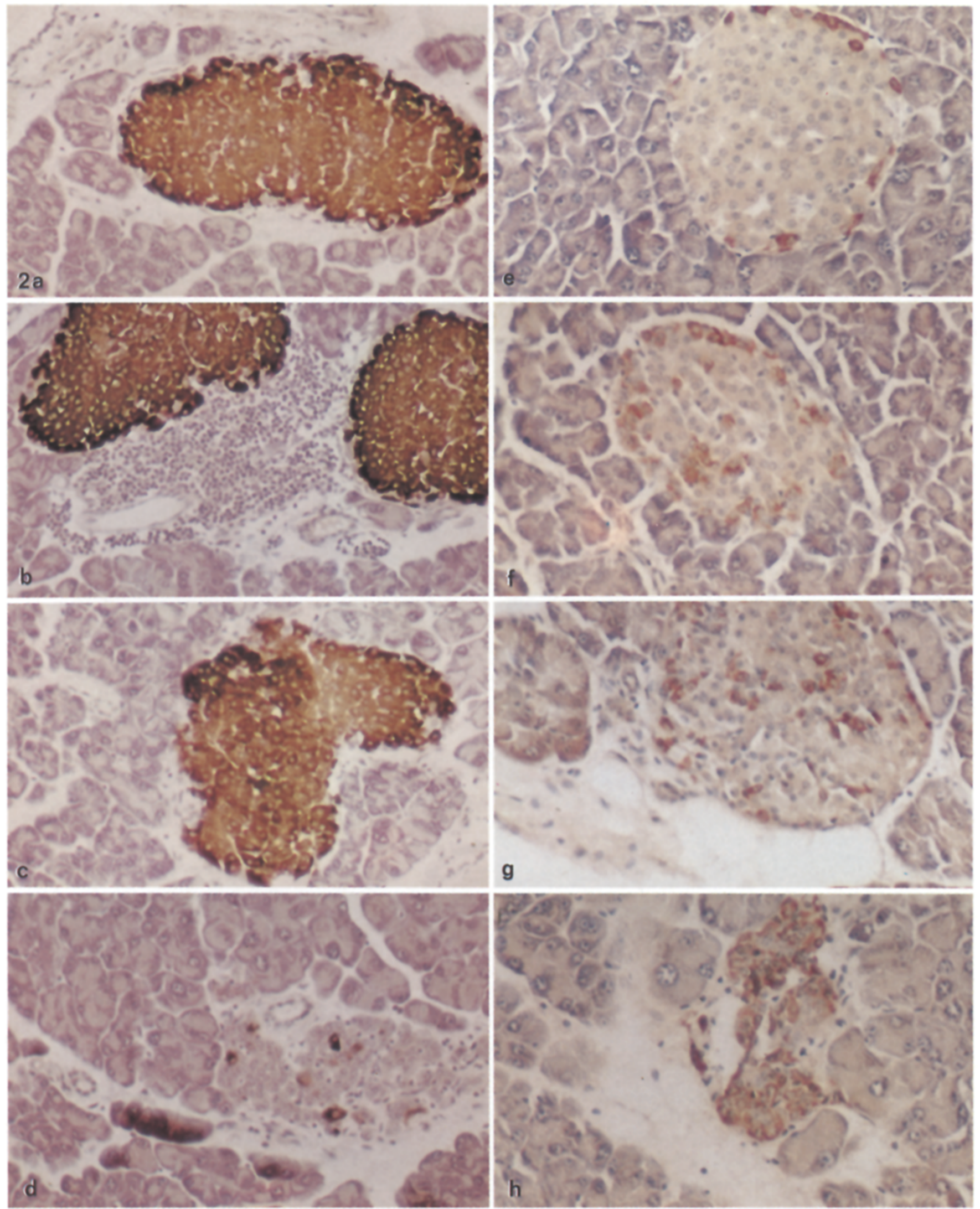

Fig. 2a-h. Immunoperoxidase staining of histological sections for immunoreactive insulin (a-d) and immunoreactive glucagon (e-h) from control mice and the three study groups 5 months after infection with EMC virus. Controls: a, e; group 1: b, f; group 2: c, g; group 3: d, h 


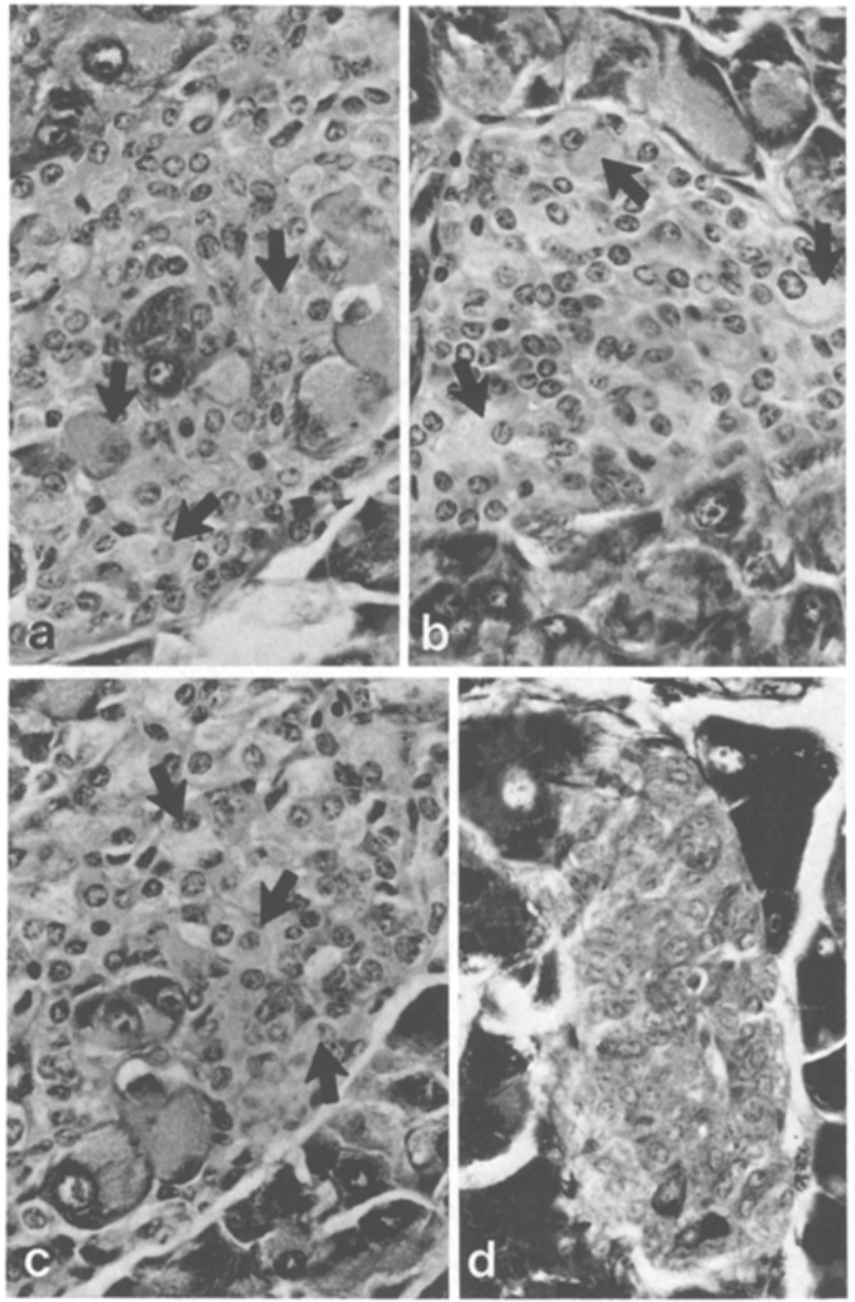

Fig. 3a-c. Selected islets of Langerhans from a mouse 8 months after infection with EMC virus. The blood glucose concentrations were $\geqslant$ $16.5 \mathrm{~m} \mathrm{~mol} / 1$ at the time of sacrifice. Note the distorted organization of the insular elements and the presence of altered acinar cells within and at the periphery of the islets. The prominent basophilic material represents hyperplastic endoplasmic reticulum (Fig.6).

Arrows denote large cells with pale staining cytoplasm that are scattered in the islets. These are believed to be the cells illustrated in Figures 4 and 5 that have a loosely-structured cytosol and a sparse endoplasmic reticulum (haematoxylin and eosin stained, $x$ 75). d Aldehyde fuchsin stained islets demonstrating the near-absence of cells containing insulin granules $(\times 75)$

ing members of group 3 was increased before and 30 min after initiation of the test.

Figure 2 illustrates the results of immunohistochemical studies to identify insulin and glucagon containing cells in the islets of control mice and members of the study groups at 5 months. The photomicrographs were prepared from the pancreases of animals used in the studies shown in Figure 1; the islets illustrated are believed to be representative of the changes observed. As seen in Figure 2, the islets of the persistently glycosuric animals were distorted in configuration and depleted of insulin. The distribution of glucagon-containing cells at the periphery of the islets in the control animals was consistent with the usual distribution of A cells. There was a tendency for these cells to be scattered within the substance of the islets in mice convalescing from infection. Glucagon-staining cells predominated in the islets of mice with persistent glycosuria (group 3).

Light and electron micrographic evaluation of the pancreatic islets of chronically diabetic mice revealed a complex picture which defies exacting interpretation (Figures 3-7). Within the islets, the cells varied in size and configuration. Many were poorly granulated and exhibited an abundant but loosely arranged endoplasmic reticulum. We believe some of these cells represented residual, degranulated B cells. Other cellular elements contained numerous dark staining granules; the fine structural morphology and distribution was consistent with A cells.

At the periphery of the islets, the acinar and endocrine cells of the pancreas were intermingled and occasional cells contained both zymogen and endocrine granules. Many of the acinar cells had an irregular configuration and exhibited an abundant endoplasmic reticulum; some extended into the substance of the contracted islets. The pattern suggested that acinar cells proliferate at the islet margin and undergo metaplasia to form endocrine elements.

\section{Discussion}

Infection of male mice of the CD-1 strain with the M variant of EMC virus results in a marked reduction in the $\mathrm{B}$ cell mass of the pancreatic islets. Individual A cells show few, if any, morphological changes and there is currently no evidence to indicate these cells are infected. Thus, during convalescence A cells are prominent in the pancreatic islets, a pattern which is observed also in streptozotocin-treated animals $[13,14]$ and patients with insulin-dependent diabetes $[15,16]$.

The studies reported here document the metabolic changes that occur in mice with varying degrees of insular injury as a consequence of EMC virus infection. Previous work has shown that the severity of the metabolic disease in these animals is variable and our results confirm this claim $[1,3,5]$. In the present investigation, we divided convalescent mice into three groups to characterize alterations in glucose tolerance and endocrine function. Members of the first group failed to exhibit glycosuria during convalescence and histological changes in the islets were subtle. Although the results of glucose tolerance tests on members of this group as a whole did not differ significantly from controls, a few individual mice evidenced diabetic curves and attenuated glucose stimulated insulin release. The animals that exhibited either transient or persistent glycosuria during convalescence from infection (groups 2 and 3) clearly were abnormal. Particularly noteworthy were the results of assays for plasma insulin and glucagon during the glucose tolerance test. The concentrations of these two 

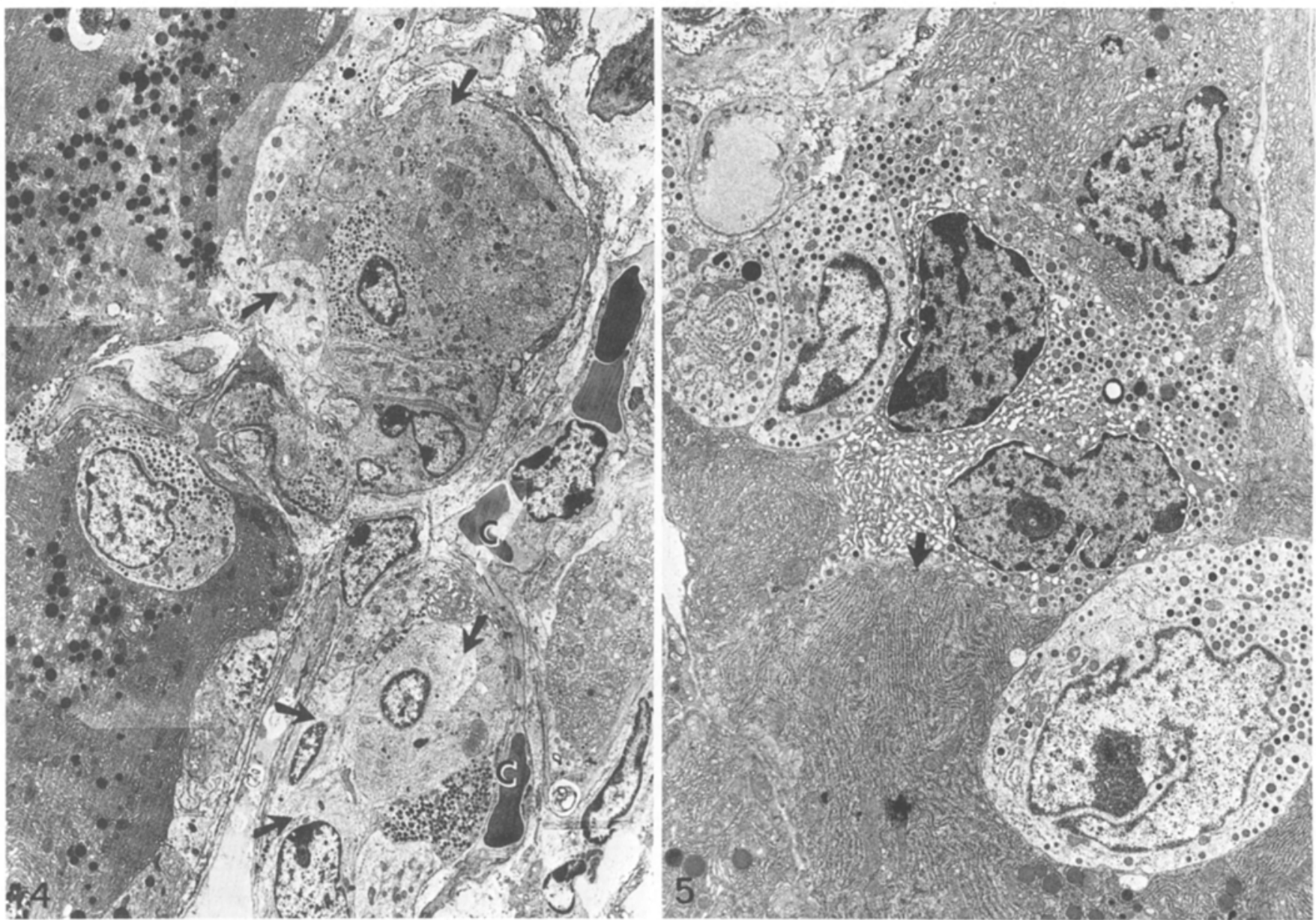

Fig. 4. Area of a mouse islet 8 months after infection with EMC virus. The blood glucose concentration was $\geqslant 16.5 \mathrm{mmol} / 1$. Note the distorted endocrine cells and their intimate association with the acinar cells. Strands of collagen are interspersed in the tissue and surround many capillaries (C). Large sparsely granulated cells similar to those in the light photomicrographs of Figure 3 are denoted by arrows $(\times 2230)$

Fig. 5. Area of a mouse islet after infection with EMC virus. The blood concentration was $\geqslant 16.5$ mmol/l. Note the intimate association of the acinar and endocrine elements and the distorted arrangement of the latter cells. A distinct plasma membrane delineating the two cell types is not defined consistently (arrow), suggesting a transition from one cell type to the other $(\times 4010)$

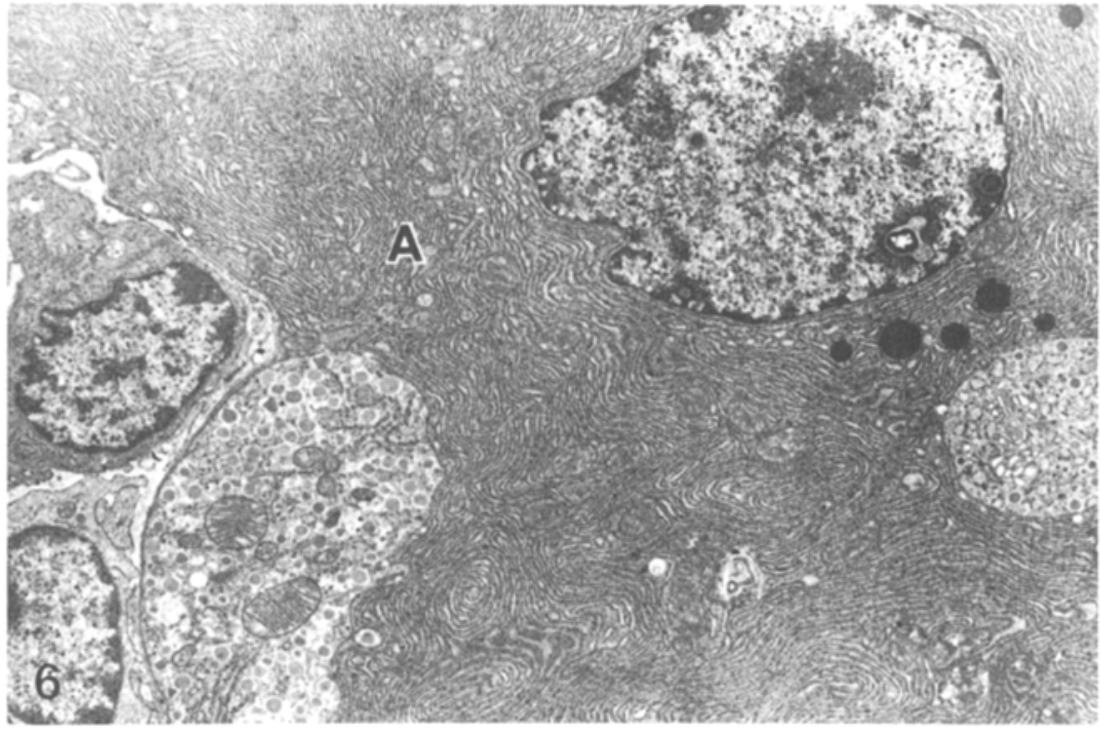

Fig. 6. Acinar cells $(A)$ with hyperplastic endoplasmic reticulum interdigitate with unidentified, distorted endocrine elements. Note the paucity of zymogen granules and the indistinct plasma membrane surrounding the endocrine component. These features suggest that the latter elements evolve from proliferating acinar cells $(\times 3580)$. This tissue is from a mouse with a blood glucose concentration of $\geqslant 16.5 \mathrm{mmol} / \mathrm{l}$, sacrified 8 months after infection 


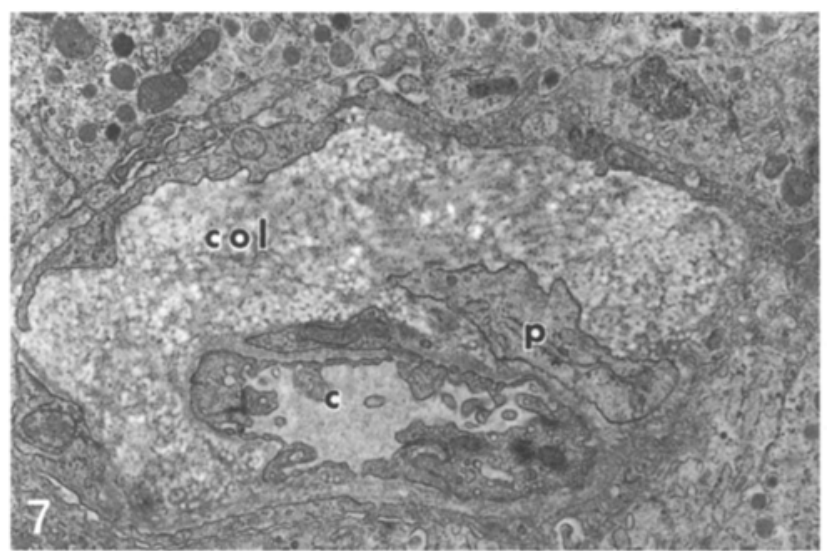

Fig. 7. A capillary ( $c$ ) in an islet of a mouse killed 9 months after infection. The blood glucose concentration was $\geqslant 16.5 \mathrm{mmol} / 1$. Dense collagen (col) accumulations encompass the capillaries in this tissue. Note the periocyte $(p)$ and the unidentified endocrine cells. The physiological importance of this lesion is not known $(\times 11,000)$

hormones were related inversely and the amounts of glucagon in the plasma were increased dramatically in animals with persistent hyperglycaemia and glycosuria.

The results of our morphological studies are consistent with these metabolic changes. Although quantitative evaluations were not carried out, the presence of glucagon containing cells in the diseased islets is apparent. Indeed, these cells seemed to predominate in the islets of mice with chronic hyperglycaemia. The picture which evolves indicates that a functional population of A cells persists in animals recovering from infection. The associated hyperglucagonaemia would appear to play a role in maintaining the elevated blood glucose concentrations in these animals.

The fine structural features of the insular cells of chronically diabetic animals are complex and the identity and functional capacity of these cells is uncertain. Detailed studies of the islets of several animals provide evidence suggestive of endocrine regeneration emanating from acinar cells at the periphery of the islets. Although mitoses were observed occasionally in the islets, the most striking changes were found in the exocrine elements. A similar phenomenon has been observed in a number of animal species under a variety of experimental situations [17]. Our studies failed to determine whether functional endocrine tissue develops as a result of these metaplastic changes. Furthermore, it is not known if the product is an endocrine cell having the capacity to fabricate either insulin or glucagon (or both).

Acknowledgements. The technical assistance of B.J.D'Andrea and H.C. West is deeply appreciated. Official management and heartful encouragement by P. Breiner are gratefully acknowledged. This work was supported by U.S. Public Health Service Grant R01 EY 02062.

\section{References}

1. Craighead JE, Steinke J (1971) Diabetes mellitus-like syndrome in mice infected with encephalomyocarditis virus. Am J Pathol 63: 119-134

2. Craighead JE, Higgins D (1974) Genetic influences affecting the occurrence of a diabetes mellitus-like disease in mice infected with the encephalomyocarditis virus. J Exp Med 139: 414-425

3. Boucher DW, Hayashi K, Rosenthal J, Notkins AL (1975) Virusinduced diabetes mellitus. III. Influence of the sex and strain of the host. J Infect Diseases 131: 463-466

4. Craighead JE, Kanich RE, Kessler JB (1974) Lesions of the islets of Langerhans in encephalomyocarditis virus-infected mice with diabetes mellitus-like disease. Am J Pathol 74: 287

5. Wellmann KF, Amsterdam D, Brancato P, Volk BW (1972) Fine structure of pancreatic islets of mice infected with the $M$ variant of the encephalomyocarditis virus. Diabetologia 8:349-357

6. Zaheer F, Howell SL, Taylor KW, Coleman TJ, Gamble DR (1979) Biochemical and ultrastructural changes in A and B cells of the islets of Langerhans of mice infected with EMC virus. Diabetologia 17: 51-57

7. Petersen K-G, Heilmeyer P, Kerp L (1975) Synthesis of proinsulin and large glucagon immunoreactivity in isolated Langerhans islets from EMC-virus infected mice. Diabetologia 11:21-25

8. Wilson GL, D'Andrea BJ, Bellomo SC, Craighead JE (1980) Encephalomyocarditis virus infection of cultured murine pancreatic beta cells. Nature 285: 112-113

9. Stefan Y, Lagae FM, Yoon JW, Notkins AL, Orci L (1978) Virusinduced diabetes in mice. A quantitative evaluation of islet cell population by immunofluorescence technique. Diabetologia 15: 395-401

10. Craighead JE (1966) Pathogenicity of the $M$ and $E$ variants of the encephalomyocarditis (EMC) virus. I. Myocardiotropic and neurotropic properties. Am J Pathol 48: 333-345

11. Hayashi K, Boucher DW, Notkins AL (1974) Virus-induced diabetes mellitus. II. Relationship between B cell damage and hyperglycemia in mice infected with encephalomyocarditis virus. Am J Pathol 75:91-102

12. Craighead JE, D'Andrea BJ, Wilson GL (1981) Effect of genetic obesity in mice on the induction of diabetes by encephalomyocarditis virus. Diabetes $30: 451-454$

13. Black HE, Rosenblum IY, Capen CC (1980) Chemically induced (streptozotocin-alloxan) diabetes mellitus in the dog. Biochemical and ultrastructural studies. Am J Pathol 98: 295-310

14. Jones CW, Reynolds WA, Hoganson GE (1980) Streptozotocin diabetes in the monkey. Plasma levels of glucose insulin glucagon and somatostatin with corresponding morphometric analysis of islet endocrine cells. Diabetes 29: 536-546

15. Gepts W (1965) Pathologic anatomy of the pancreas in juvenile diabetes mellitus. Diabetes 14: 619-633

16. Maclean N, Ogilvie RF (1955) Quantitative estimation of the pancreatic islet tissue in diabetic subjects. Diabetes $4: 367-376$

17. Melmed RN (1979) Intermediate cells of the pancreas. In: Glass GBT (ed) An appraisal. Progress in Gastroenterology, Grune \& Stratton, New York, pp 196-201

Received: 25 August 1982

and in revised form: 11 April 1983

Dr. J.E. Craighead

Department of Pathology

Medical Alumni Building

University of Vermont

Burlington, VT 05405

USA 